\title{
DROBNÉ PREDMETY Z ÚZEMIA JUHOZÁPADNÉHO SLOVENSKA ${ }^{1}$
}

\author{
Gertrúda Březinová
}

DOI: https://doi.org/10.31577/szausav.2019.suppl.1.4

Keywords: Southwestern Slovakia, miniature figurines, Iron Age

\section{Miniature artefacts from the territory of Southwestern Slovakia}

The objects are part of a larger collected group including a number of various artefacts mainly made of bronze and iron which are dated from the Bronze Age to the Modern Era. They were obtained from sites situated in the Trnavská pahorkatina hills and near Skalica. The artefacts are mainly animal figurines, one is a human figurine, a phallus-shaped pendant and a shoe-shaped pendant. Rings, pendants and an object with undetermined function are also represented.

\section{ÚVOD}

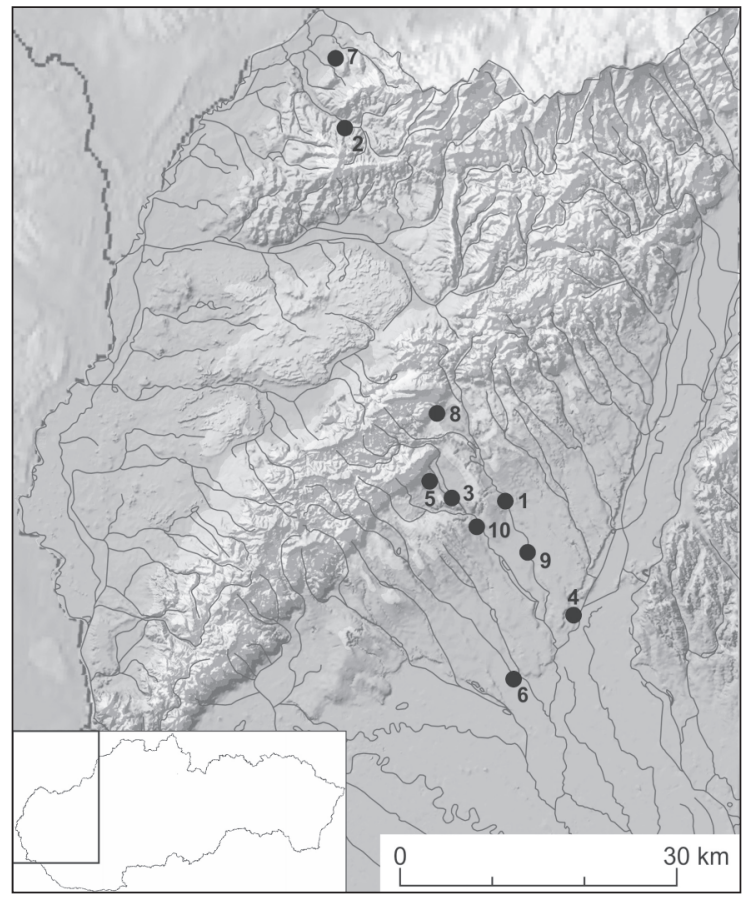

Obr. 1. Náleziská s výskytom drobnej kovovej plastiky. 1 - Bohdanovce nad Trnavou; 2 - Dubovce; 3 - Košolná; 4 - Križovany; 5 - Dolné/Horné Orešany; 6 - Pavlice; 7 - Skalica; 8 - Smolenice; 9 - Trnava; 10 - Zvončín.
S rozšírením povrchovej prospekcie dochádza $\mathrm{v}$ poslednej dobe $\mathrm{k}$ nárastu množstva drobných kovových predmetov, ktoré pochádzajú z lokalít datovaných aj do doby laténskej. Nie vždy sa tieto predmety dajú jednoznačne datovat. Tie, ktoré prezentujeme $\mathrm{v}$ príspevku sú z nálezísk na Trnavskej pahorkatine a z okolia Skalice. ${ }^{2}$ Predmety podobného charakteru boli z týchto lokalít už skoršie publikované T. Kolníkom a V. Mitášom (2012, 35-74), ako aj I. Bazovským (2014, 615-620), kde je i staršia literatúra $\mathrm{k}$ téme. Ide o územia, ktoré boli v dobe laténskej intenzívne osídlené. Predpokladáme, že pochádzajú zo sídlisk s datovaním od staršej až po mladšiu dobu železnú (obr. 1). Pokúsime sa postupne charakterizovat predmety a hladat' analógie $\mathrm{k}$ ich datovaniu. Zväčša ide o plastiky zvieratiek, iba v jednom prípade o plastiku človeka, závesok $\mathrm{v}$ tvare falusa a $\mathrm{v}$ tvare topánky. Sú tu zastúpené aj krúžky, závesky, spona, koráliky a predmet neznámeho účelu. Pri triedení nálezov postupujeme podla klasifikácie vypracovanej M. Čižmářom, v ktorej spracoval drobnú kovovú plastiku z Moravy (Čižmár̆ 2012, 145-173).

1 Práca vznikla v rámci grantového projektu 1/0243/17 agentúry VEGA a bola podporovaná Agentúrou na podporu výskumu a vývoja na základe Zmluvy č. APVV-15-0491.

2 Pochádzajú zo zberovej činnosti a autorke príspevku boli poskytnuté na zdokumentovanie a publikovanie. Presnejšia lokalizácia uvedených lokalít nie je vždy známa aj z dôvodu spôsobu získania týchto predmetov. 


\section{OPIS PREDMETOV}

\section{Zvieracia plastika}

1. Bohdanovce nad Trnavou, okres Trnava, v doline potoka Trnávky (tab. I: 4). Bronzová plastika koníka s naznačenou hrivou a chvostom. Jedna noha je dvihnutá. Šírka plastiky $4 \mathrm{~cm}$ a maximálna výška $4 \mathrm{~cm}$.

2. Križovany nad Dudváhom, okres Trnava. Plastika zvieratka so vztýčenou hlavou s uškami. Na chrbte sa nachádza uško na prevlečenie šnúrky pre zavesenie (tab. I: 5). Plastika je z bronzoviny s váhou $27,1 \mathrm{~g}$. Šírka 3,6 cm a výška 4,5 cm. Pravdepodobne ide o srnku.

3. Orešany, Dolné/Horné Orešany, okres Trnava (tab. I: 3). Bez bližšej identifikácie lokality, či ide o Horné alebo Dolné. ${ }^{3}$ Ide o plastiku koníka zhotovenú z bronzoviny. Váha 27,4 g. Koník má sklopenú hlavu a nohy mierne v pohybe. Šírka tela je 2,8 cm a maximálna výška 3,5 cm. Chrbát plastiky je skoro štvorhranný a v strede sa nachádza kruhový otvor s priemerom $6 \mathrm{~mm}$.

4. Pavlice, okres Trnava, bez bližšieho určenia polohy. Plastika zvieratka z bronzoviny. Váha 22,3 g (tab. I: 1). Zvieratko je na podstavci s dížkou 3,5 cm. Výška je $2 \mathrm{~cm}$. Má zvýraznené uši, jedno je zvesené nadol. Pravdepodobne ide o psíka.

5. Pavlice, okres Trnava, bez bližšieho určenia polohy. Ide o zvieratko s obojstranne situovanými hlavičkami a zvýraznenými končatinami (tab. II: 1) zhotovené z bronzoviny. Jedna postavička je 2,5 cm vysoká a druhá $2 \mathrm{~cm}$. Spoločná čast’ tela má šírku $3 \mathrm{~cm}$. V strede sa nachádza prepojenie, ako keby na prevlečenie šnúrky, kože, na zavesenie. Hmotnost’ 27,4 g. Pravdepodobne ide o psíka, srnku (?).

6. Pavlice, okres Trnava, bez bližšieho určenia polohy. Plastika zvieratka na chrbte s prevliečkou (tab. II: 2). Bronzovina, hmotnost' 19,6 g. Výška plastiky 2,8 cm a šírka 3,5 cm. Na zvieratku sú zvýraznené oči, náznak uší. Má štyri nohy a chvostík. Zdá sa, že ide o psíka.

7. Zvončín, okres Trnava. Dolina potoka Parná (tab. I: 2). Výška 1,2 cm, rozpätie nožičiek 1,7 cm z boku a spredu 0,7 $\mathrm{cm}$. Je dost̉ nahrubo vypracovaná, zhotovená z bronzoviny. Váha 4,2 g. Na chrbte je akýsi pásik bez bližšej identifikácie.

8. Zvončín, okres Trnava. Dolina potoka Parná (tab. III: 6). Drobný poškodený závesok ukončený vtáčou hlavičkou. Váha 9,3 g. Výška zachovalej časti 1,5 cm, šírka $1 \mathrm{~cm}$. Prierez oválny.

9. Neznáma lokalita v okrese Trnava. Plastika robustného býčka zhotovená z bronzoviny s prepracovanými detailmi rohov, očí, pysku a chvosta (tab. II: 3). Jedna noha je ulomená. Výška 5 cm, šírka 6,5cm. Váha 133,4 g.

\section{Ludská plastika}

\section{Plastika celej postavy}

1. Smolenice, okres Trnava, poloha Molpír (tab. III: 1). Plastika muža vo výške $5 \mathrm{~cm}$. Materiál olovo. Váha 221 g. Postava je ako keby v pohybe. Pravá ruka je vzpažená. Na tejto ruke sa nachádzajú v hornej časti dva malé výčnelky. L'avá ruka je mierne spustená $\mathrm{k}$ telu. Z vnútornej strany je oblá priehlbinka, náznak dlane (?). Hlava nie je velmi prepracovaná. Sú tu naznačené iba ústa a jedno oko. Na prsiach sú dva zárezy a na chrbte jeden, ktoré pripomínajú prevesenie nejakého predmetu (zbrane ?). Sedacia čast’ je pevnejšia, uspôsobená na to, že predmet bol niekde posadený, upevnený. Nohy sú rozkročené. Nad kolenami sú záseky, ktoré evokujú ukončenie nohavíc, prípadne naznačujú kolená.

\section{Závesok $v$ podobe falusa}

1. Zvončín, okres Trnava. Dolina potoka Parná (tab. III: 4). Výška závesku aj s očkom $3 \mathrm{~cm}$. V očku je ešte krúžok z retiazky. Predmet zhotovený z bronzoviny, váha 4,6 g. Prierez kruhový, povrch hladký.

\section{Závesok v podobe nohy}

1. Košolná, okres Trnava. Dolina potoka Parná (tab. III: 7). Výška prívesku aj s očkom je 1,8 cm. Dĺžka topánky je tiež 1,8 m. Zhotovená je z bronzoviny. Váha 3,2 g. Vnútro je duté.

\section{Ostatné závesky a krúžky}

1. Bohdanovce nad Trnavou, okres Trnava. Závesok z bronzoviny hruškovitého tvaru (tab. III: 3). Jedna čast’ zvýraznená obvodovou lištou, spodná zaoblená a hlavička je rozdelená troma oblúčikmi. Výška 2,8cm. Váha 10,0 g.

2. Zvončín, okres Trnava. Hruškovitý závesok z bronzoviny (tab. III: 5). Výška $3 \mathrm{~cm}$. Váha 7,9 g. V hornej časti je prevliečka, ktorú od tela rozdeluje obvodová lišta. Tá je aj medzi spodnou a stredovou častou.

3. Bohdanovce nad Trnavou, okres Trnava. Krúžok, na ktorom sú tri pozdĺžne závesky. Na jednom z nich je zachované aj očko z retiazky. Krúžok má vonkajší priemer 1,8 cm a váhu 2,9 g. Zhotovený je z bronzoviny (tab. IV: 1).

4. Bohdanovce nad Trnavou, okres Trnava. Jednoduchý krúžok s otvorenými koncami. Priemer 2,4 cm, váha 4,5 g. Bronzovina (tab. IV: 2).

3 Z uvedených lokalít sú početné drobné nálezy, ktoré možno datovat aj do doby rímskej. Z toho dôvodu zaradenie do doby železnej je iba orientačné. 
5. Bohdanovce nad Trnavou, okres Trnava. Krúžok z bronzoviny s vonkajším priemerom 2,5 cm a váhou 4,6 g. Na krúžok nadväzujú v priečnom postavení menšie krúžky s priemerom 0,8 cm (tab. IV: 5 ).

6. Bohdanovce nad Trnavou, okres Trnava. Krúžok z bronzoviny s vonkajším priemerom 2,8 cm a váhou 8,7 g (tab. IV: 6). Po obvode, ktorý je rozdelený na tri časti, sú po troch kusoch hráškovité náliatky.

7. Bohdanovce nad Trnavou, okres Trnava. Krúžok z bronzoviny s priemerom 2,5 cm a váhou 3,4 g (tab. IV: 7). Z vonkajšej strany sú na štyroch miestach hráškové náliatky (v rovnakých rozstupoch). Po obvode sú náliatky husto za sebou.

9. Bohdanovce nad Trnavou, okres Trnava. Bronzový krúžok, kde vnútorný kruh je pravidelný a vonkajší hrbol’atý. Náliatky (21) sú na vonkajšej i vnútornej stene (4). Vonkajší priemer 2,4 cm a váha 7,3 g (tab. IV: 10). Materiál bronzovina.

10. Bohdanovce nad Trnavou, okres Trnava. Bronzová zoomorfná zápona z opaska s ukončením v podobe hlavy koníka (tab. III: 2). Váha 11,8 g. S vel'kou pravdepodobnostou ide o súčast̉ retazového opaska.

11. Dubovce, okres Skalica. Jednoduchý bronzový krúžok s oválnym prierezom. Priemer vonkajšej časti $2,5 \mathrm{~cm}$ a hmotnost' 4,1 g (tab. IV: 8). Materiál bronzovina.

12. Trnava, pri potoku Trnávka, okres Trnava. Krúžok s priemerom $2 \mathrm{~cm}$. Po obvode má tri dvojice náliatkov. Váha 3,1 g. Materiál bronzovina (tab. IV: 3).

13. Trnava, pri potoku Trnávka, okres Trnava. Krúžok s priemerom 2 cm a váhou 3,1 g. Materiál bronzovina. Po obvode pät zvýraznených výčnelkov (tab. IV: 4).

14. Trnava, pri potoku Trnávka, okres Trnava. Deformovaný krúžok s priemerom $2 \mathrm{~cm}$ a váhou 3,4 g. Materiál bronzovina (tab. IV: 9).

\section{Ostatné nálezy}

1. Bohdanovce nad Trnavou, okres Trnava. Predmet neznámeho účelu (ingot ?). Váha 69,4 g. Tvar, akoby čakan s ryhami (tab. III: 11).

2. Dubovce, okres Skalica. Malý bronzový korálik s cik-cak obvodovou líniou. Vonkajší priemer 1 cm (tab. III: 8).

3. Dubovce, okres Skalica. Zlomok bronzového drôtika, ktorý mohol byt použitý na výrobu spony (?). Dížka 9,3 cm (tab. III: 10).

4. Skalica, okres Skalica. Sklený korálik modrej farby s priemerom 0,9 cm (tab. III: 9).

5. Trnava, okres Trnava. Spona železná, neskorolaténskej schémy. Dížka 7,3 cm. Obojstranné vinutie 2 × 2 . Váha 9,0 g (tab. III: 12).

\section{ANALÝZA PREDMETOV}

V úvode sme uviedli, že ide o predmety nejasného datovania a nie vždy s presnou identitou náleziska. Sú súčastou zberom získanej väčšej kolekcie, kde sa nachádza množstvo rôznorodých predmetov hlavne z bronzu a železa, s datovaním od doby bronzovej až po novovek. Boli získané z nálezísk, ktoré sú situované na Trnavskej pahorkatine a z okolia Skalice. V príspevku prezentujeme tie drobné predmety, ktoré s vel'kou pravdepodobnostou patria do doby železnej. Žial', bez d’alších sprievodných nálezov je toto datovanie problematické. Dôvod, prečo ich prezentujeme v uvedenej práci je, že nálezov podobného charakteru pribúda nielen na Slovensku, ale aj v okolitých krajinách. Napriek nejasným nálezovým okolnostiam, obohacujú naše poznanie o živote a predstavách prehistorických spoločenstiev a zároveň dopíňajú mapu nálezísk v sledovanom priestore. Spracovanie starších nálezov, ako aj novšie revízne výskumy môže napomôct' $\mathrm{k}$ ich bližšiemu datovaniu.

Plastika v podobe ludskej postavy je zo Smoleníc, z polohy Molpír. S vel'kou pravdepodobnostou patrí do staršej doby železnej, kedy sa na Molpíre nachádzalo výšinné hradisko s významným postavením v rámci doby halštatskej (Dušek/Dušek 1984). Je zhotovená z olova a svojím stvárnením skôr inklinuje k ludským plastikám, ktoré poznáme z východnej časti Álp a z Talianska, kde postavy sedia zväčša na koňoch (Foresti 1981, napr. tab. VI: 4; VII: 6). Ďalšie skúmané predmety patria do skupiny záveskov a amuletov. Plnili viacero úloh. Okrem toho, že svojim nositelom dodávali želané vlastnosti a odvahu, mali aj ochrannú funkciu pred rôznymi negatívnymi javmi. Závesok $\mathrm{v}$ podobe falusa je zo Zvončína (tab. III: 4). Vyhotovením má podobnost’ so záveskami hruškovitého tvaru s očkom na zavesenie. Ako analógiu k stvárneniu možno použit závesok obojstranného falusa zo Starého Hradiska (Čižmář 2012, obr. 6: 7). Závesok v podobe nohy sa vyskytuje v nálezovom inventári ovela častejšie. Noha alebo topánka sú rôzne upravené. Niekedy sú plné, dosť často však aj duté, ako je to aj v prípade závesku z Košolnej (tab. III: 7). Analógie sú v Nemčiciach (Čižmář 2012, obr. 7) a aj na iných lokalitách stupňa LTC na Morave (Čižmár 2012, obr. 8) a zo Slovenska napríklad v Chorvátskom Grobe (Pieta 2008, F36: 2). Plastiky zvieratiek v rôznych vyhotoveniach a vel'kostí sú známe v celom keltskom svete. Dá sa povedat', že každá figúrka je originál. Nenašli sa dve zhodné plastiky. Zo Slovenska je doteraz známych okolo 20 figúrok 
(Pieta 2008, 301). V sledovanom súbore predmetov sú tri plastiky koníka z Bohdanoviec nad Trnavou (tab. I: 4), z Križovian nad Dudváhom (tab. I: 5) a z Orešian, otázne je, či z Dolných alebo Horných (tab. I: 3). ${ }^{4}$ Kone si Kelti vysoko cenili. Mali vlastnú patrónku, bohyňu menom Epona. Bola uctievaná ako bohyňa plodnosti a prosperity.

K dalším plastikám patria predmety z Pavlíc. A to psík (tab. I: 1), psík (alebo srnka) s obojstranne situovanou hlavičkou (tab. II: 1) a zvieratko na chrbte s prevliečkou, pravdepodobne psík (tab. II: 2). Asi psík je aj zvieratko zo Zvončína (tab. I: 2). Pes bol kultovým zvieratom božstiev podsvetia a symbolizoval nielen zánik, ale zároveň aj ochranu zdravia a života. K oblúbeným záveskom patrili i tie, ktoré znázorňovali vtákov. Jeden poškodený závesok je zo Zvončína (tab. III: 6). Pravdepodobne ide o vodného vtáka. K často zobrazovaným zvieratám patrí býk (Pieta 2008, 301). Bol obetným zvieratom, sprievodcom vládcu nebies a znázorňoval silu, plodnoste. Plastika robustného býčka je z neznámej lokality z okresu Trnava. Datovanie je tu velmi otázne. K častým drobným predmetom patria aj závesky z opaskov. Dva hruškovitého tvaru sú z Bohdanoviec nad Trnavou (tab. III: 3; IV: 1).

Amulety a prívesky dopíňajú rôzne zdobené, prípadne nezdobené kolieska. Často sa vyskytujú spolu s predmetmi ozdobného charakteru ako spínadlá, koráliky, prstencové korále, prípadne mince. Na Slovensku je to súbor nálezov z Plaveckého Podhradia a Kolačna (Čambal 2017, tab. XLIX; Pieta 2008, F23). K zaujímavým predmetom patria krúžky s hráškovými náliatkami, ktoré zo Starého Hradiska spracovali M. Dębiec a M. Karwowski (2014). Drobné kovové predmety sú predmetom štúdie z Čiech (Mangel/ Vích 2012, 439-442) a z územia Malé Hané (Vích 2017). Autori M. Dẹbiec a M. Karwowski (2016, 115-146) krúžkovité závesky na území Bójov spracovali aj v typologickej štúdii. Často sa používa názov prevzatý z nemčiny, tzv. Knotenringe, alebo nevel'ké krúžky z bronzu, ktoré majú na vonkajšej strane rôzne hráškovité náliatky. Boli považované za predmety datované do neskorej doby laténskej. Poznáme ich hlavne z Moravy, na prilahlom území Rakúska, Pol’ska i Slovenska. Dopĺňajú predmety, ktoré svedčia o vztahoch a kontaktoch s územím Slovinska a severného Talianska (Božič 1998; Čižmář 2012, 150). Západnou hranicou ich výskytu je Česká kotlina, teda západná čast’ osídlenia spojená s tzv. „bójskou menou" (Militký 2008, 122). Najvýraznejšia koncentrácia je na Morave, v širokom koridore tzv. Jantárovej cesty. Ich funkcia je otázna. Pravdepodobne slúžili ako prívesky, prstene, mohli spájat’ odev, alebo mohli byṫ súčastou konského postroja. Predpokladá sa, že mali aj aj symbolickú a náboženskú funkciu. Po podrobnom spracovaní týchto predmetov sa ich datovanie upresnilo od LTC1 až do LTD. K súčastiam opaska patrí zoomorfná zápona s ukončením v tvare hlavy koníka. Na základe celkového vyhotovenia patrí k mladším typom, ktorý sa už nevyskytuje na plochých keltských pohrebiskách (Bujna 2011, 139, tu i zoznam ostatných nálezísk). Na základe nálezov zo Slovenského Grobu a Němčíc ju možno datovat do LTC1-C2, prípadne až do LTD1 (Čambal 2011, tab. XI: 1a, 1b; Čižmář/Kolníková 2006, 264). Podobná zápona sa našla aj v nedalekom Radimove (Bača/Břrzinová 2016, 21-23). Z ostatných nálezov je to predmet neznámeho účelu z Bohdanoviec nad Trnavou, ktorý mohol slúžit ako ingot (?), a neskorolaténska železná spona z Trnavy, ktorá má svoje analógie v Manchingu. Podla R. Gebhardta ide o skupinu 24a, ktorá vychádza zo stredolaténskych spôn skupín 24-29 (Gebhardt 1991, 87, tab. 46).

\section{CHARAKTERISTIKA NÁLEZÍSK}

Na základe posledného súpisu sídliskových lokalít z územia juhozápadného Slovenska je zrejmé, že Trnavská tabul'a a tiež aj Záhorie boli intenzívne osídlené od staršej po neskorú dobu laténsku (Březinová 2006, mapa 1; 2). Ide hlavne o lokality sídliskového charakteru, menej o pohrebiská. Najviac sú však evidované nálezy získané zberovou činnostou. Lokality sa rozprestierajú tak na úrodných pôdach po oboch stranách Malých Karpát, ako aj na prilahlých vyvýšeninách.

\section{Východná strana Malých Karpát a Trnavská tabula}

Priestor Malých Karpát patril k strediskám keltského osídlenia už v čase príchodu tohto etnika do oblasti stredného Dunaja. Najnovšie výsledky prieskumu a výskumu tejto oblasti potvrdzujú, že ide o najvýchodnejšiu čast’ včasnolaténskeho osídlenia, ktorá sa ešte donedávna predpokladala v oblasti

\footnotetext{
4 Z uvedených lokalít sú početné drobné nálezy, ktoré možno datovat aj do doby rímskej. Z toho dôvodu zaradenie do doby železnej je iba orientačné.
} 
Treisenu v Dolnom Rakúsku. Zmeny nastali po objavení lokality z daného časového úseku v Horných Orešanoch. Na rozhraní chotárov Dolných a Horných Orešian sa nachádza poloha Slepý vrch, kde sa uskutočnili v rokoch 2002-2005 zberové i výskumné aktivity záchranného charakteru pod vedením K. Pietu. Výskum potvrdil významné hradisko a sídlisko s datovaním od HD do LTA (Pieta 2007, 295-310). V súbore nami hodnotených predmetov z Orešian pochádza plastika koníka. Nie je však zrejmé, z ktorej časti Orešian. Predpokladáme, že jeho datovanie je mladšie ako nálezy zo Slepého vrchu. V čase existencie výšinného hradiska na Slepom vrchu poznáme sídliská v sledovanej oblasti v Rakoviciach a v Trnave-Hornom poli, ktoré časovo korešpondujú s pohrebiskami v Bučanoch a Stupave. Osídlenie v strednej dobe laténskej je potvrdené uprostred Trnavskej pahorkatiny v Budmericiach, Cíferi-Páci, Čataji a v d’alších polohách. Práve do tohto horizontu možno zaradit závesky zo Zvončína (tab. III: 6), Košolnej (tab. III: 7), Bohdanoviec na Trnavou (tab. I: 4), Križovian nad Dudváhom (tab. I: 5), Pavlíc (tab. I: 1; II: 1, 2) a z Trnavy. Zo Zvončína pochádza zo zberu v polohe Medziháje II (Marková/Samuel 2003) laténska keramika. Nedávno boli publikované aj dva sklené náramky typu Haevernick 7c a 11a (Čambal/Štrbík 2014), ktoré iba potvrdzujú osídlenie územia aj v priebehu strednej a neskorej doby laténskej.

\section{Západná strana Malých Karpát a rieka Morava}

Na Záhorskej nížine boli zakladané osady s koncentráciou pozdĺž lavého brehu rieky Moravy, napríklad Devínska Nová Ves, Kúty, Zohor, Šaštín-Stráže a intenzívnejšie osídlenie v okolí Plaveckého Podhradia, predovšetkým na výšinnej polohe Pohanská (Čambal 2008; 2017, 329). Z publikovaných sídlisk je to Zohor (Elschek/Kolníková 2014) a zo spracovaných pred publikovaním Studienka (Čambal 2017), pričom sa predpokladá, že sídlisko v Studienke malo priamy súvis s tažbou limonitu a tvorilo zázemie keltskému výšinnému sídlisku Pohanská. V hodnotenej zbierke máme k dispozícii iba sklený korálik modrej farby s priemerom $0,9 \mathrm{~cm}$ zo Skalice (tab. III: 9). Tieto typy korálikov však majú dlhé obdobie používania a nie sú vhodným predmetom na spresnenie chronológie. Z Duboviec je jednoduchý bronzový krúžok s oválnym prierezom, ktorý tiež poskytuje širší okruh pre datovanie. Z publikovaných nálezov poznáme z centra mesta Skalica fragmenty nádob s datovaním do doby laténskej (Drahošová 1996, 41). Ide však tiež iba o nálezy zberového charakteru.

\section{ZÁVER}

Drobné kovové artefakty, ktoré sú predmetom tejto štúdie, možno zaradit (väčšinu z nich) medzi symbolické predmety, ktoré slúžili na ochranu svojho nositela pred zákonmi a zvykmi vtedajšieho sveta. Všetky pochádzajú z povrchových zberov na sídliskách, takže je vel’mi problematické vyjadrił sa k ich bližšiemu datovaniu. Oporou pre datovanie sú nálezy z Plaveckého Podhradia a Radimova (aj ked’ ide o predmety získané nelegálnou činnostou). V kolekcii z Plaveckého Podhradia sa nachádzajú sklené šperky (Pieta 2008, 368, F23), ktoré umožňujú datovat tieto nálezy do LTC, maximálne na začiatok LTD1. Dobrou paralelou $\mathrm{k}$ datovaniu nálezov sú nedávno publikované predmety z Radimova (Bača/Březinová 2016), kde sa okrem bronzovej ludskej plastiky našiel i fragment náramku a závesky podobné tým, ktoré poznáme zo sledovaného súboru predmetov. Analógie sú aj na druhej strane rieky Moravy, predovšetkým v Nemčiciach a v Starom Hradisku (Čižmář 2012; Debiec/Karwowski 2014, 667-681; 2015). Okrem plastiky zo Smoleníc, ktorá je staršia, možno ostatné nálezy datovat najskôr do stupňa LTC (závesky, zvieracie plastiky, sponu, koráliky; čast’ až do LTD). Otvorené zostáva datovanie plastiky býčka (tab. II: 3). 

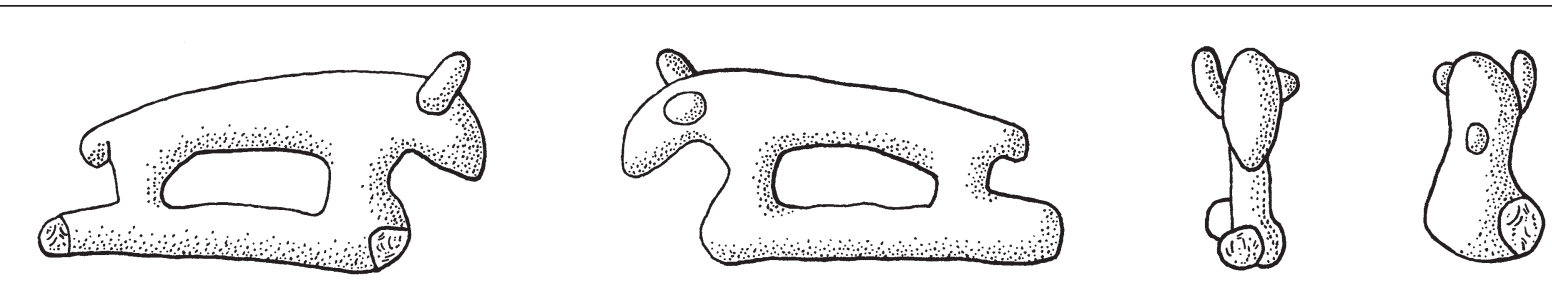

1
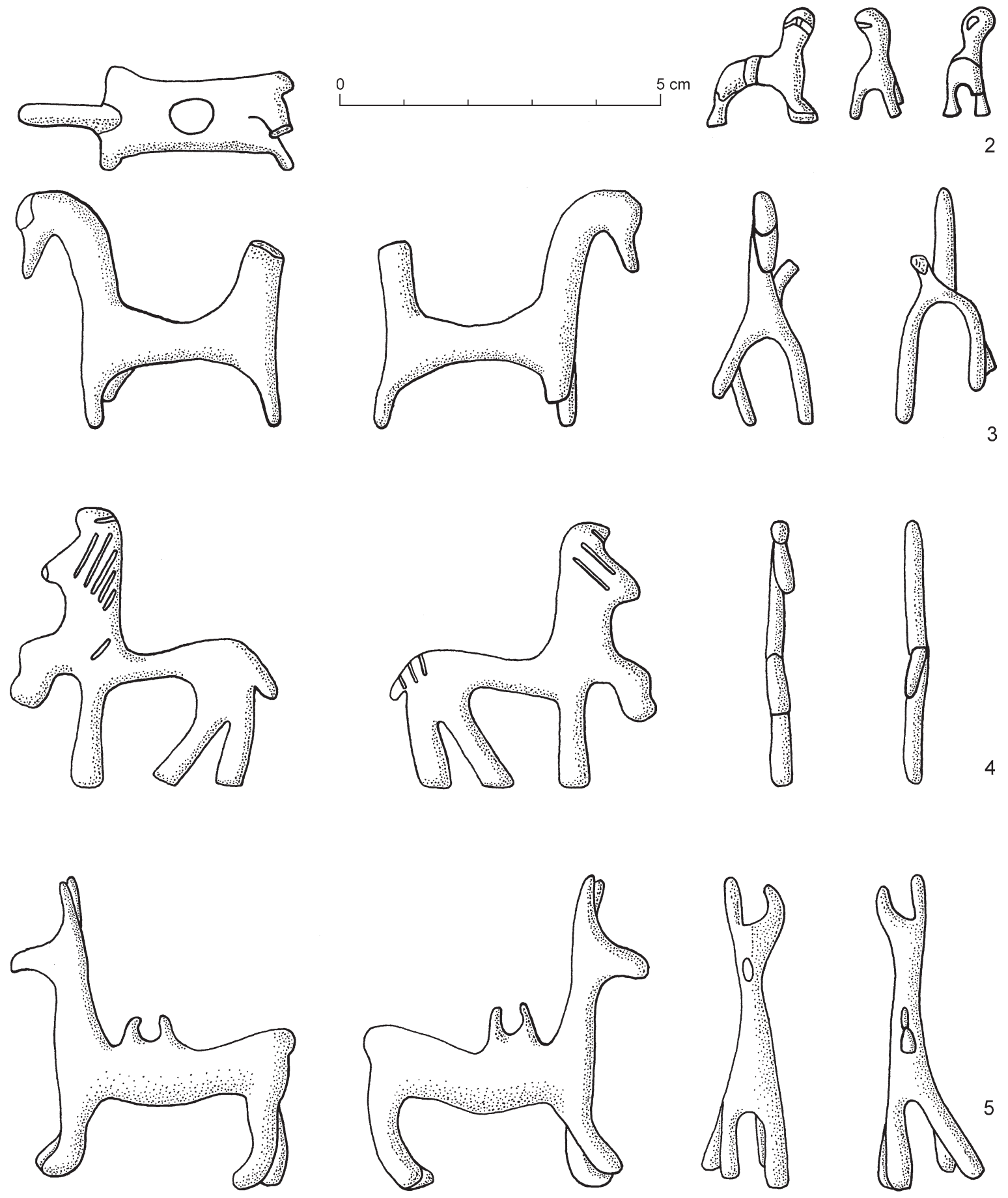

Tab. I. Drobné bronzové predmety. 1 - Pavlice; 2 - Zvončín-Parná; 3 - Orešany, Dolné/Horné Orešany; 4 - Bohdanovce nad Trnavou; 5 - Križovany nad Dudváhom. 
DROBNÉ PREDMETY Z ÚZEMIA JUHOZÁPADNÉHO SLOVENSKA

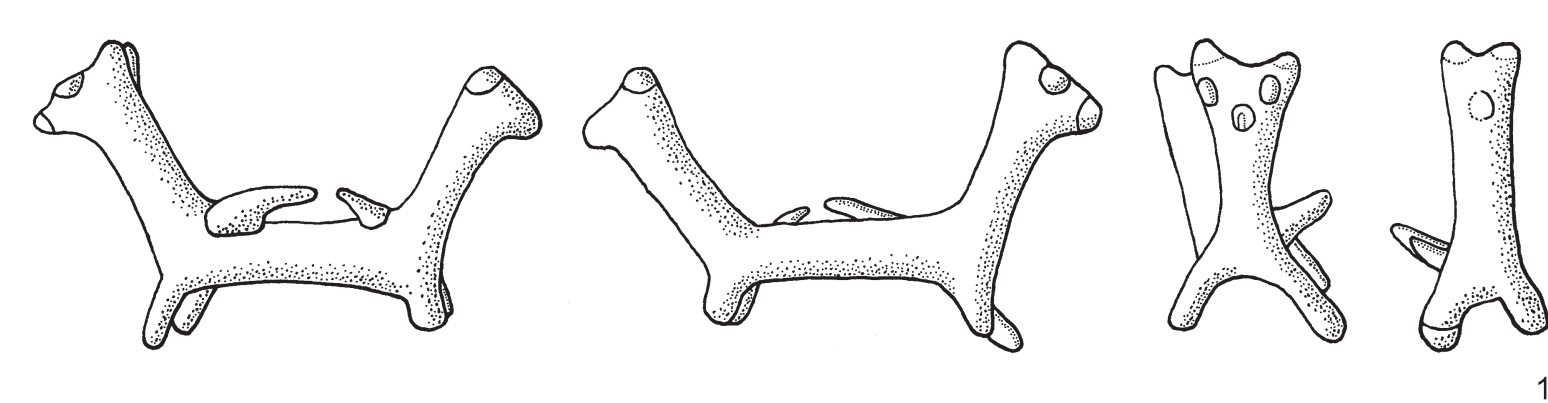

1
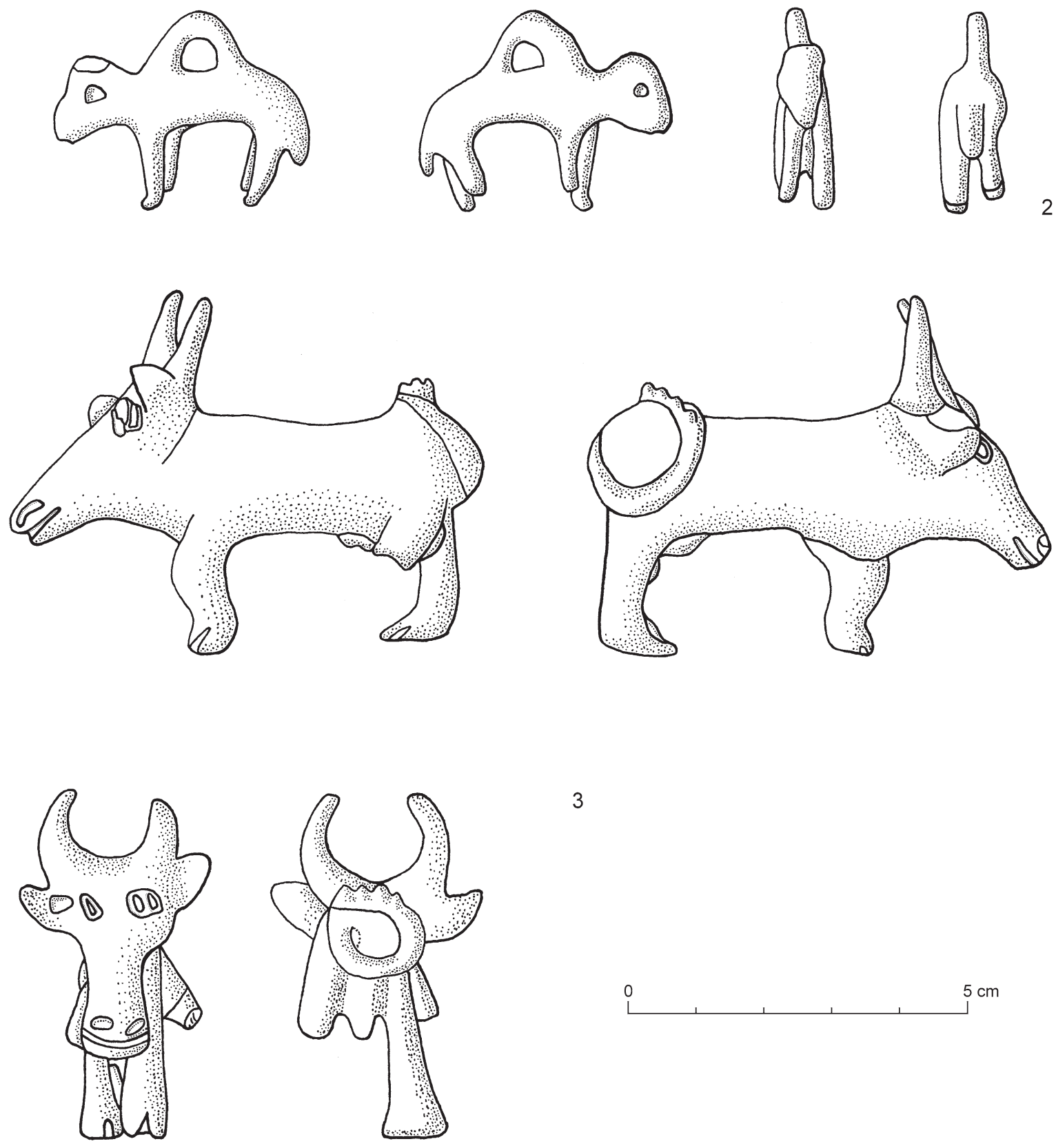

3

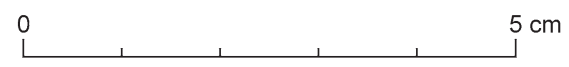

Tab. II. Drobné bronzové predmety. 1, 2 - Pavlice; 3 - neznáma lokalita. 
100

GERTRÚDA BŘEZINOVÁ

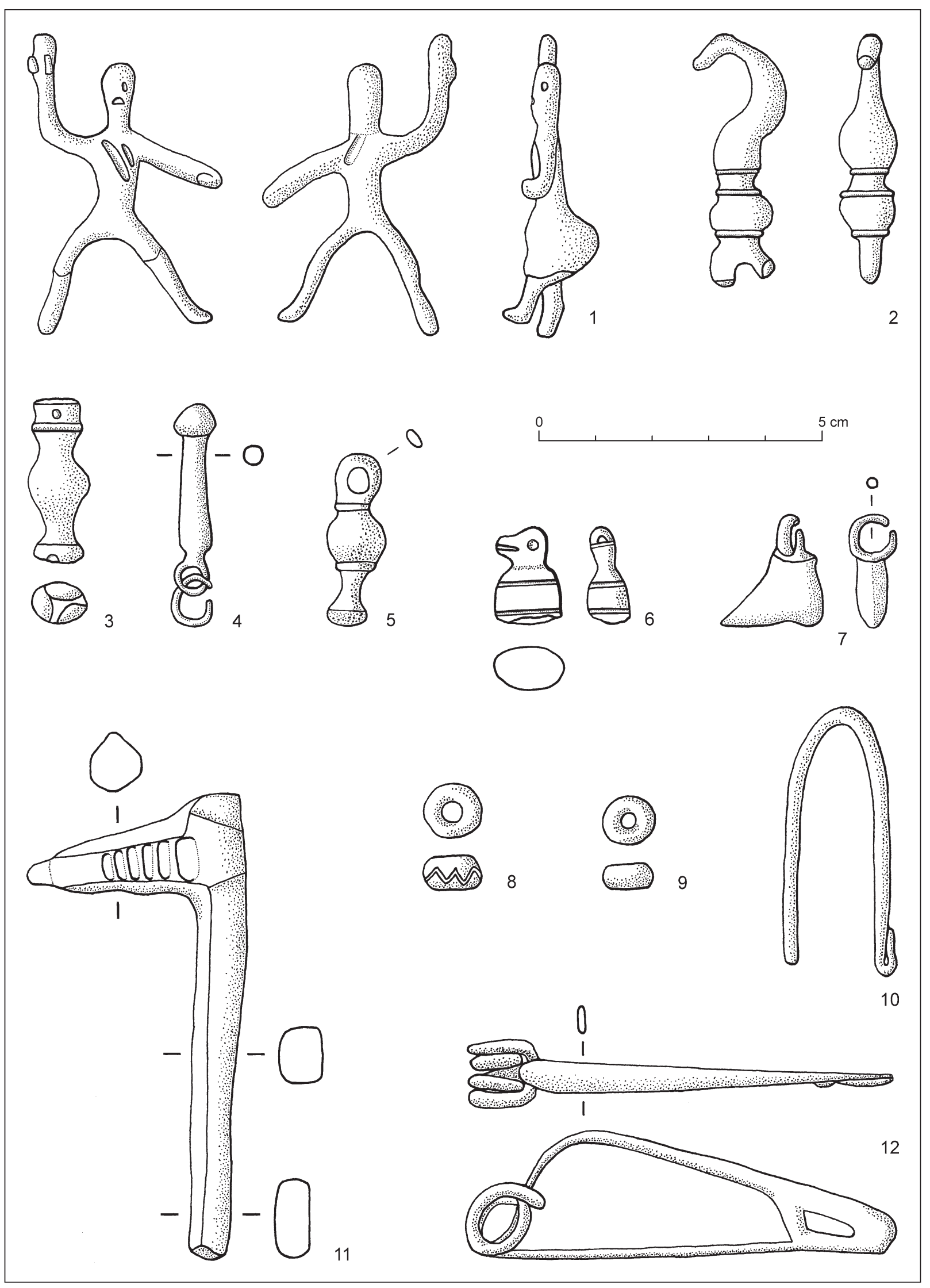

Tab. III. Drobné kovové predmety. 1 - Smolenice-Molpír; 2, 5, 11 - Bohdanovce; 3, 4, 6 - Zvončín-Parná; 7 - Košolná; 8 Dubovce; 9 - Skalica; 10 - Dubovce; 12 - Trnava. 1 - olovo; 12 - železo; ostatné bronz. 
DROBNÉ PREDMETY Z ÚZEMIA JUHOZÁPADNÉHO SLOVENSKA

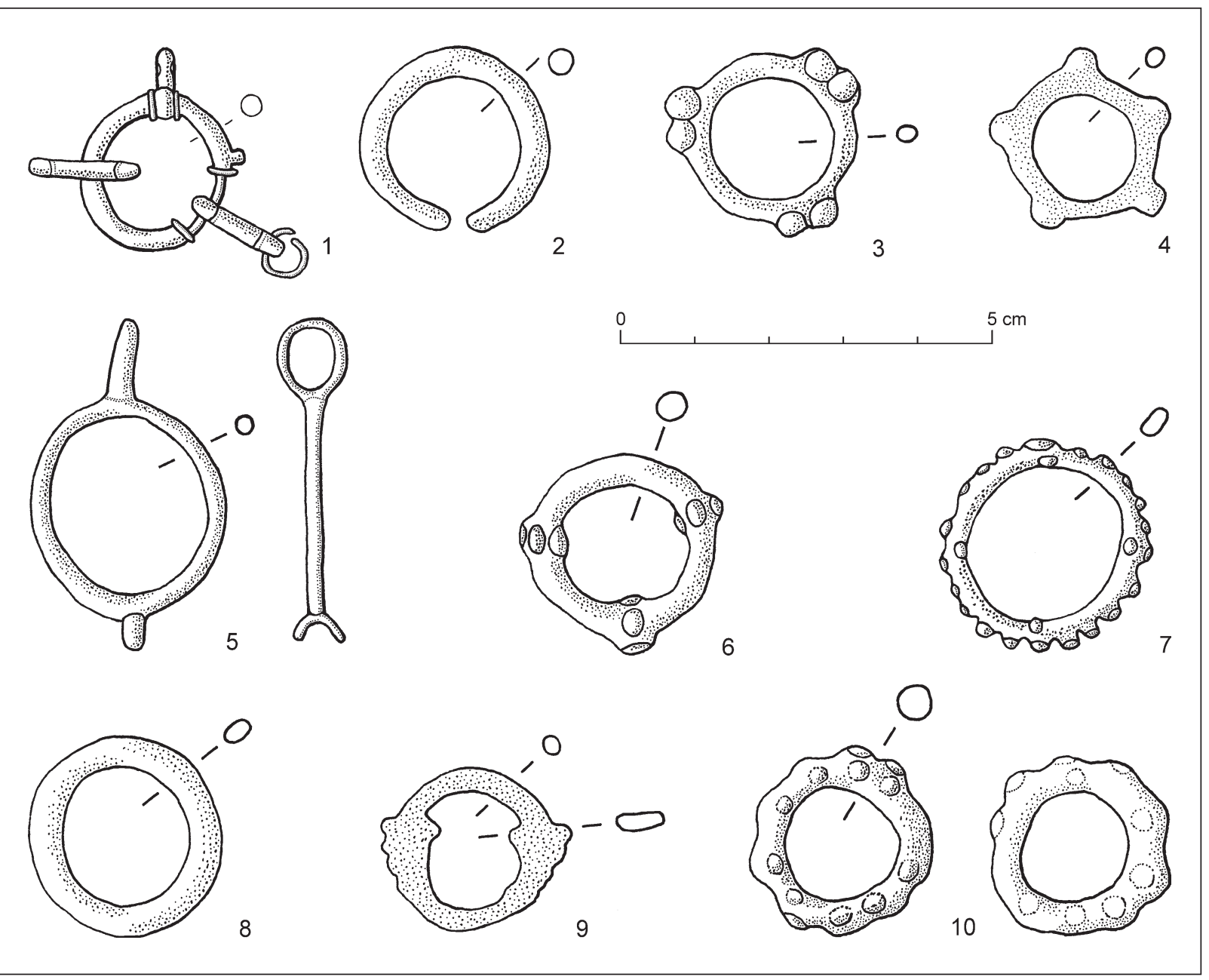




\section{LITERATÚRA}

Bača/Březinová 2016

Bazovský 2014

Božič 1998

Březinová 2006

Bujna 2011

Čambal 2008

Čambal 2011

Čambal 2017

Čambal/Štrbík 2014

Čižmář 2012

Čižmář/Kolníková 2006

Dębiec/Karwowski 2014

Dębiec/Karwowski 2016

Drahošová 1996

Dušek/Dušek 1984

Elschek/Kolníková 2014

Foresti 1981

Gebhardt 1991

Kolník/Mitáš 2012

Mangel/Vích 2012

Marková/Samuel 2003

Militký 2008

Pieta 2007

Pieta 2008

Vích 2017
R. Bača/G. Březinová: Drobné nálezy z doby laténskej z Radimova. Archeologické výskumy a nálezy na Slovensku v roku 2011, 2016, 21-23.

I. Bazovský: Bronzové predmety z Križovian nad Dudváhom (okr. Trnava, JZ Slovensko). In: J. Čižmářová/N. Venclová/G. Březinová (ed.): Moravské křižovatky: Střední Podunají mezi pravěkem a historií. Brno 2014, 615-620.

D. Božić: Neues über die Kontakte längs der Bernsteinstrasse während der Spätlatènezeit. Arhaeološki Vestnik 49, 1998, 141-156.

G. Březinová: Sídliská a sídliskové nálezy z laténskej doby na juhozápadnom Slovenku. Študijné zvesti Aú SAV 40, 2006, 9-50.

J. Bujna: Opasky ženského odevu doby laténskej. Nitra 2011.

R. Čambal: Osídlenie okresov Bratislava, Senec a Pezinok v dobe laténskej. In: P. Pospechová/P. Wittgrúber (zost.): Carnuntum-Gerulata. Pezinok 2008, 101-117.

R. Cambal: Sídliskové objekty zo strednej a neskorej doby laténskej v Slovenskom Grobe. Zborník SNM 105. Archeológia 21, 2011, 83-114.

R. Čambal: Laténske osídlenie Záhoria (Filozofická fakulta UK). Dizertačná práca. Bratislava 2017. Nepublikované.

R. Čambal/J. Štrbík: Keltské náramky z povodia Malokarpatských potokov. Zborník SNM 108. Archeológia 24, 2014, 103-126.

M. Čižmář: Nálezy drobné lidské a zvířecí plastiky z Moravy. In: G. Březinová/V. Varsik (ed.): Archeológia na prahu histórie. K životnému jubileu Karola Pietu. Archaeologica Slovaca Monographiae. Communicationes XIV. Nitra 2012, 137-143.

M. Čižmář/E. Kolníková: Němčice - obchodní a industriální centrum doby laténské na Moravě. Archeologické rozhledy 58, 2006, 261-283.

M. Dębiec/M. Karwowski: Celtic Knotenringe from Staré Hradisko. In: J. Čižmářová/N. Venclová/G. Březinová (ed.): Moravské křižovatky. Střední Podunají mezi pravěkem a historií. Brno 2014, 667-680.

M. Dębiec/M. Karwowski: A Typological Study of the La Tène Knotenringe in the Territory of the Boii. In: M. Karwowski/P. C. Ramsl (ed.): Boii - Taurisci. Proceeding of the Internatiional Seminar. Oberleis-Klement, June $14^{\text {th }}-15^{\text {th }}$, 2012. Mitteilungen der Praehistorischen Kommission 85. Wien 2016, 115-146.

V. Drahošová: Výsledky prieskumu v Skalici. Archeologické výskumy a nálezy na Slovensku v roku 1994, 1996, 41, 42.

M. Dušek/S. Dušek: Smolenice-Molpír. Befestigter Fürstensitz der Hallsttatzeit I. Nitra 1984.

K. Elschek/E. Kolníková: Beitrag zur Datierung der latènezeitlichen Zentralsiedlung von Zohor in der Westslowakei. Kleinfunde, keltische und frührömische Münzen. In: J. Čižmářová/N. Venclová/G. Březinová (ed.): Moravské křižovatky: Střední Podunaji mezi pravěkem a historií. Brno 2014, 353-377.

L. A. Foresti: Der Ostalpenraum und Italien: ihre kulturellen Beziehungen in Spiegel antropomorphen Kleinplastik aus Bronze des 7. Jh. S. v. Chr. Firenze. Studio Etruschi Italici 3. Firenze 1981.

R. Gebhard: Die Fibeln aus dem Oppidum von Manching. Die Ausgrabungen in Manching 14. Stuttgart 1991.

T. Kolník/V. Mitáš: Archeologické nálezy k osídleniu Bohdanoviec nad Trnavou a niekol'ko poznámok k činnosti detektoristov. Študijné zvesti AÚ SAV 51, 2012, 35-74. T. Mangel/Z. Vích: Nové laténské metalické nálezy z východních Čech a severozápadní Moravy. In: G. Březinová/V. Varsik (ed.): Archeológia na prahu histórie. K životnému jubileu Karola Pietu. Archaeologica Slovaca Monographiae. Communicationes XIV. Nitra 2012, 439-443.

K. Marková/M. Samuel: Ďalšie nálezy zo Zvončína. Archeologické výskumy a nálezy na Slovensku v roku 2002, 2003, 82.

J. Militký: Mincovnictví v době laténské. In: N. Venclová (ed.): Archeologie pravěkých Čech 7. Doba laténská. Praha 2008.

K. Pieta: Der frühlatènezeitliche Burgwall in Horné Orešany, Westslowakei. Vorbericht. Slovenská archeológia 55, 2007, 295-310.

K. Pieta: Keltské osídlenie Slovenska. Mladšia doba laténska. Archaeologica Slovaca Monographiae. Studia XI. Nitra 2008.

D. Vích: Doba laténská v severní části Boskovické brázdy ve světle drobných kovových nálezů. Archeologické rozhledy 69, 2017, 629-671 


\title{
Miniature artefacts from the territory of Southwestern Slovakia
}

\author{
Gertrúda Březinová
}

Summary

The discussed artefacts cannot be dated with certainty and the exact identity of the site cannot always be determined. They are part of a larger collected group including a number of various artefacts mainly made of bronze and iron which are dated from the Bronze Age to the Modern Era. They were obtained from sites situated in the Trnavská pahorkatina hills and near Skalica (Fig. 1). The article presents those miniature artefacts which most probably belong to the Iron Age (Pl. I-IV). Unfortunately, this dating is questionable without other accompanying finds. The reason why we present them in this article is that the number of such objects is increasing not only in Slovakia but also in its neighbouring countries. In spite of the unclear find context, they enrich our knowledge of life and ideas of prehistoric societies and they also complete the map of sites in the studied territory. Future and processing of older finds can help with their dating. The artefacts are mainly animal figurines, one is a human figurine, a phallus-shaped pendant and a shoe-shaped pendant. Rings, pendants and an object with undetermined function are also represented (Pl. IIV). Classification of these finds follows from the classification elaborated by M. Čižmár $(2012,145-173)$, in which he processed miniature metal figurines from Moravia.

Fig. 1. Southwestern Slovakia, localization of miniature metal artefacts. 1 - Bohdanovce nad Trnavou; 2 - Dubovce; 3 - Košolná; 4 - Križovany; 5 - Orešany, Dolné/Horné Orešany; 6 - Pavlice; 7 - Skalica; 8 - Smolenice; 9 - Trnava; 10 - Zvončín.

Pl. I. Miniature bronze artefacts. 1 - Pavlice; 2 - Zvončín-Parná; 3 - Dolné/Horné Orešany; 4 - Bohdanovce nad Trnavou; 5 - Križovany nad Dudváhom.

Pl. II. Miniature bronze artefacts. 1, 2 - Pavlice; 3 - unknown site.

Pl. III. Miniature metal artefacts. 1 - Smolenice-Molpír; 2, 5, 11 - Bohdanovce; 3, 4, 6- Zvončín-Parná; 7 - Košolná; 8 Dubovce; 9 - Skalica; 10 - Dubovce; 12 - Trnava. 1 - lead; 12 - iron; other - bronze.

Pl. IV. Miniature bronze artefacts. 1, 2, 5-7, 10 - Bohdanovce; 3, 4, 9 - Trnava; 8 - Dubovce.

Translated by Viera Tejbusová

doc. PhDr. Gertrúda Březinová, CSc.

Archeologický ústav SAV

Akademická 2

SK - 94901 Nitra

gertruda.brezinova@savba.sk 
